\title{
How to Do a Naked Presentation
}

\section{COMMUNICATION CORNER No. 17}

\section{by Philip Yaffe}

\section{Editor's Introduction}

Each "Communication Corner" essay is self-contained; however, they build on each other. For best results, before reading this essay and doing the exercise, go to the first essay "How an Ugly Duckling Became a Swan," then read each succeeding essay.

A "naked" presentation solely relies upon good storytelling. Learn how to enrapture an audience without the use of visual aids. 


\title{
How to Do a Naked Presentation
}

\author{
COMMUNICATION CORNER No. 17
}

\section{by Philip Yaffe}

For many speakers today, the question of whether or not to illustrate a presentation is a nonstarter. Of course you illustrate! Well yes and no. Like everything else in a text or a speech, anything that doesn't add to it subtracts from it. So the first question to ask is: Do I really need illustrations (visuals)?

However, the next question to ask is definitely not: What visuals do I need?

Visuals should be used to advance the purposes of the presentation, not dominate it. Thus, the first thing you should do is write out the speech with no thought of visuals. If you first write a well-constructed speech, then where visuals are needed or would be useful will become obvious. Likewise for what the visuals should and, just as important, should not illustrate.

I call a speech written with no thought of visuals a "naked presentation."

The following naked presentation was delivered to a group of diplomats, business executives, academics, and other professionals in Brussels (Belgium). Although it used no visual aids (slides are only one kind of visual aid), it kept the audience spellbound. See if you can determine why.

\section{HOW TO DO THIS EXERCISE}

The exercise consists of two parts.

In Part I, labeled the "Original," you will see the introduction to the speech as it might have been written by someone unfamiliar with the principles and practices you have learned in previous "Communication Corners." This will be followed by an "Analysis" to highlight the introduction's strengths and weaknesses.

- Cover the page so that only the Original is visible and read the text.

- As you read, make notes about what you think is good in the Original and what you think needs to be done to improve it.

- Uncover the Analysis and compare it with your notes.

In Part 2, you will see the introduction to the speech as it was actually delivered. 
- Cover the page so that only the Original is visible and read the text.

- As you read, make notes about what you think is good in the Original and what you think needs to be done to improve it.

- Uncover the Analysis and compare it with your notes.

You don't have to agree with everything in the Analysis for each part. Everyone has slightly different ways of looking at a speech. However, if you strongly disagree with anything in the Analysis, ask yourself "why?" In particular, ask yourself what fundamental principle or principles you believe are being applied poorly, or not at all.

\section{Part 1: The Speech as It Might Have Been Written}

\section{Original}

I would like to talk to you this evening about a man I admire very much. His name is Julius Nyerere and he was the first president of Tanzania after it gained independence from Britain in 1961.

Julius Nyerere was born in 1922 in Butiama, a small village in what was then Tanganyika. He was the son of Nyerere Burito, a Zanaki tribal chief. At that time schools were in very short supply. Julius began attending Government Primary School at the age of 12, which he completed in three years instead of the standard four. He did equally well in secondary school and won a scholarship to Makerere University in Uganda, then the only university in all of East Africa.

When he returned to Tanganyika, he worked for three years as a secondary school teacher of biology and English. He then won a scholarship to attend the University of Edinburgh, where he obtained a Master of Arts degree in history and economics. This is where he began developing the ideas and tactics that ultimately helped him lead Tanganyika to independence from Britain and become the independent country's first president. Unlike many other independence movements at the time, he achieved this feat without a single drop of blood being shed.

\section{Analysis}

[The speech continues...]

This speech seems to get off to a good start. It immediately tells the audience what the speaker will talk about and who he is going to talk about. Because most people in the audience probably will never have heard of Julius Nyerere, it immediately answers the question: "Who is he?" Remember, whenever you raise a question in your reader's or listener's mind, it is essential to answer it; otherwise you risk losing mind control.

All of this is quite good. However, the introduction largely ignores the expository writing (expository speaking) attitude: No one wants to read (listen to) what you are going to say. 
Therefore, your first objective, before anything else, is to give them reasons for doing so. It is only when we learn Julius Nyerere led his country to independence without a single drop of blood being shed-a rare occurrence in the liberation movements of the 1960s-does the man really begin to sound interesting.

Thus, while this introduction gives a lot of data, it gives little information. In short, it fails to rapidly engage the audience's interest.

\section{Part 2: The Speech as It Was Actually Written}

\section{Original}

We live in a cynical world where the values of truth, honesty, and integrity seem to be in short supply. We are therefore always looking for examples of such values in action, especially with regard to politicians.

I would like to offer you just such an example from Africa. You may never have heard of him, but for me he stands as a true model of integrity. Can you guess who he might be? [Speaker waits a few seconds to give the audience a moment to think, and for dramatic effect. He then resumes.] No, it is not Nelson Mandela. However, I am certain Mr. Mandela would have been more than pleased to be compared to this person.

His name is Julius Nyerere. Julius Nyerere was the man who led Tanganyika, today called Tanzania, to independence from Britain in 1961. Unlike many other independence movements of the time, this one succeeded without a single drop of blood being shed.

I had the privilege of living two years in Tanzania shortly after independence. Being from Los Angeles, for me Tanzania was quite a revelation. I virtually lived in a mud hut, suffered through a drought, saw leprosy, and contracted both malaria and dysentery. All of these things affected me. But getting to know Julius Nyerere as a political leader was truly a life-changing experience. When Nyerere became head of state in 1961, he was so popular that he could easily have taken on the trappings of a king or potentate. But he did exactly the opposite. He chose to live very modestly, because that was his nature.

More importantly, he inspired confidence in everyone and never betrayed that confidence, because that also was his nature. He of course had political opponents, but they were critical of certain of his ideas and policies - never the man. The worst I ever heard anyone say about him was, "President Nyerere is doing all the wrong things for all the right reasons."

Julius Nyerere was a realist riding a wave of idealism.

[The speech continues...] 


\section{Analysis}

We live in a cynical world where the values of truth, honesty, and integrity seem to be in short supply. We are therefore always looking for examples of such values in action, especially with regard to politicians.

- This first paragraph makes a broad generalization with which most of the audience will probably agree. They are therefore already somewhat on the speaker's side.

- It also suggests the speaker is about to offer a counterexample to this gloomy generalization, thereby titillating the audience's interest.

I would like to offer you just such an example from Africa. You may never have heard of him, but for me he stands as a true model of integrity. Can you guess who he might be? [Speaker waits a few seconds to give the audience a moment to think, and for dramatic effect. He then resumes.] No, it is not Nelson Mandela. However, I am certain Mr. Mandela would have been more than pleased to be compared to this man.

- This paragraph confirms the suggestion that the speaker will give a counterexample. But only partially. By promising an example from Africa, the speaker raises the speculation in the audience's mind that he is going to talk about Nelson Mandela, probably the only African leader of world stature most of them have ever heard of.

- By asking the question "Can you guess who he might be?" the speaker confirms the audience in their speculation.

- He then reverses the situation by declaring that it isn't Nelson Mandela, but someone whom Mr. Mandela himself would have greatly admired. This heightens the audience's attention and engagement.

His name is Julius Nyerere. Julius Nyerere was the man who led Tanganyika, today called Tanzania, to independence from Britain in 1961. Unlike many other independence movements of the time, this one succeeded without a single drop of blood being shed.

- Note the repetition of the name Julius Nyerere. Since most of the audience will probably never have heard of him, they are likely not to grasp the name the first time it is mentioned, so it is immediately repeated.

- Julius Nyerere is identified as the man who led Tanganyika, now Tanzania, to independence. This is a distinction, but hardly outstanding. However, the speaker immediately says this happened "without a single drop of blood being shed," a very rare occurrence. The audience gets its first clue as to what makes this man so special.

I had the privilege of living two years in Tanzania shortly after independence. Being from Los Angeles, for me Tanzania was quite a revelation. I virtually lived in a mud hut, suffered through a 
drought, saw leprosy, and contracted both malaria and dysentery. All of these things affected me. But getting to know Julius Nyerere as a political leader was truly a life-changing experience.

- The speaker reveals how he knows about Julius Nyerere. And why, despite all the other life-changing experiences he had in going from Los Angeles to Tanzania, he puts the opportunity to observe Julius Nyerere at the top of the list.

- Talking about his personal relationship with Nyerere is not a self-serving diversion. It confirms the speaker's authority on the subject. This is yet another means of heightening audience attention, engagement, and confidence in the reliability of the information they are about to receive.

When Julius Nyerere became head of state in 1961, he was so popular that he could easily have taken on the trappings of a king or potentate. But he did exactly the opposite. He chose to live very modestly, because that was his nature.

More importantly, he inspired confidence in everyone and never betrayed that confidence, because that also was his nature. He of course had political opponents, but they were critical of certain of his ideas and policies - never the man. The worst I ever heard anyone say about him was, "President Nyerere is doing all the wrong things for all the right reasons."

Julius Nyerere was a realist riding a wave of idealism.

- Enough teasing. By now the audience is fully captured and ready for some concrete examples of the man and his accomplishments.

- Note the transitional sentence: "Julius Nyerere was a realist riding a wave of idealism." By introducing the examples with a broad generalization, the speaker knits them all together to support a thesis rather than giving the impression that they are isolated incidents chosen at random.

(Here is the rest of the speech. Decide for yourself if it fulfills the promise of its well-crafted introduction.)

For example, shortly after taking office, he cut the salaries of all government ministers by 20-50 percent, including his own. Although by world standards they were very poorly paid, by Tanzanian standards they were very rich. Nyerere argued that such a poor country simply couldn't afford to maintain its government in such a lavish style. Any minister who refused the cut was invited to leave the government, and a number of them did.

In the 1960s, the first thing a newly independent country wanted to do was set up a national airline and rush to industrialize. Nyerere was different. He concluded that Tanzania could not 
become truly industrialized for at least a hundred years. So instead of devoting all its energies and limited resources to trying to build an industrial base, it made more sense to strengthen its agricultural base.

In particular, this meant reforming the schools. Instead of turning out potential clerks, shop assistants, and middle managers for the cities, the goal should be to turn out scientific farmers who would go back to their villages to teach their compatriots, who were mainly subsistence farmers.

Advocating this was close to heresy. Most people felt that the purpose of going to school was precisely to escape from the backward rural villages. There was considerable opposition to Nyerere's idea, but finally it was implemented.

As a teacher in a boarding school at the time, I could immediately see the difference. Suddenly we were required to start a school farm and to grow much of the food the students would be eating. The students didn't take kindly to having to do manual labor, but eventually the protests died down and farming became part of the daily routine.

At roughly the same time, Nyerere looked at Tanzania's university students, who were the elite of the elite. You must understand that there were only about a thousand university students in the entire country out of a population of nearly 10 million. This was because Tanzania had virtually no schools. At the age of six, less than half the children were in school. There was a stringent examination to go from primary to secondary school, which nearly 85 percent failed because there just wasn't any place for them. And at university, as I said, they were the elite of the elite.

Nyerere noted that it took the total annual income of 78 Tanzanians to keep one university student in school for one year. To help cover the cost, he proposed that on graduation each university student should give two years to paid public service. Once again, rebellion. The students went on strike. Once again, Nyerere stood his ground. He said: "As much as we need university graduates, we need Tanzanians more." He closed the university for a year and sent the students back to their villages to rediscover their roots. Those who received good reports from their village headman were allowed to return the following year.

When he retired as head of state in 1985, he took on the role of a roving diplomat and peacemaker. Because he was so trusted, he was invited to facilitate and mediate to settle disputes all across the African continent. For instance, he was instrumental in bringing an end to the slaughter in Burundi in 1996.

Nyerere didn't look like the consummate leader he was. He was rather small and had a bushy little mustache that made him look like a chocolate Charlie Chaplain. But when he spoke and when he wrote, you knew you were in the presence of someone special. He was affectionately known 
as Mwalimu. This is Swahili for teacher, which is what he was before going into politics. This was a sign of respect, not reverence.

I am not a very emotional person. But when Julius Nyerere died on October 14, 1999, I felt a sudden emptiness in me. It was as if something good had left the world. And it had.

Julius Nyerere was a devout Catholic and in 2005 he was proposed for beatification. He is currently under consideration for canonization, which is one step away from sainthood. I don't think I would put him on such a high pedestal. I didn't necessarily agree with everything he did. But I never doubted that it was always for the best of reasons.

Every time I hear his name, I still feel the same emptiness I felt on the day he died. So if you are ever tempted to say that politics and integrity don't mix, please remember Julius Nyerere. You will never find a better model of integrity-either in politics or in daily life.

\section{MATHEMATICAL MAGIC}

Writing and speaking clearly and concisely is a leitmotiv of the "Communication Corner." Early in the series, I put myself to the test by writing instructions for a self-working card trick without supporting diagrams or photos. Since no one asked for clarification, presumably I succeeded.

In the words of Robert Louis Stevenson, author of Kidnapped, Treasure Island, and The Strange Case of Dr. Jekyll and Mr. Hyde: "Don't write merely to be understood. Write so that you cannot possibly be misunderstood."

If you can achieve this, you can write anything - and say anything in a speech to the plaudits of you audience.

Here is an extremely simple trick that baffles many people who believe they know something about mathematics, but it should be a snap for computer scientists and programmers.

I can't describe it in detail here because it is an apparent demonstration that it is possible to read minds via the internet. I will give you the URL in a moment.

Basically, you are asked to do pick at random any two-digit number from 10 to 99, then to perform a simple calculation on it. No matter what number you choose, the website will tell you the result of the calculation. And no, it's not because you get the same result every time. The result is quite variable, yet the website never misses.

You can find the trick at: http://www.curiouser.co.uk/illusions/mindreader3.htm I will tell you why it works in the next installment. 
Good luck. And have fun.

\section{HOMEWORK: Retrospective to Communication Corner No. 16}

In CC16, you were given what is perhaps the most important homework assignment of the entire "Communication Corner" series, so I would like to ask you to do it again.

\section{Homework from CC16}

I normally don't approve of rote learning, i.e. memorizing things word for word. However, there are exceptions. Sometimes key ideas seem so simple or self-evident that, believing they have been fully grasped, people internalize them and push them to a subconscious level.

However, simple or self-evident ideas are often perceived this way because they harbor profound truths. Thus, internalizing them to the point of the subconscious can diminish their practical impact.

It has been my experience that while applying key ideas almost automatically, the best writers and speakers every so often bring these ideas to the conscious level to ensure they aren't forgetting or minimizing or overlooking something important. I know I certainly do this, and I recommend that you do so too.

Therefore, as homework I enjoin you to learn and remember certain key ideas word for word so you can call on them word for word whenever you feel the need to do so.

Here are the key ideas I believe you should know both consciously and subconsciously.

- Expository Writing Attitude

No one wants to read what you write

- Expository Speaking Attitude

No one wants to hear what you say

- Precise definition of Clear $\left(C_{L}=E D E\right)$

- Precise definition of Concise $\left(C_{0}=\mathbf{L S}\right)$

- Precise definition of Dense $(\mathbf{D}=\mathbf{P L})$

- Inverted pyramid: key information grouped at the top; secondary information (details) flow towards the bottom 
- 5 Ws \& H (who, what, when, where, why, how)

- A series of short sentences often gives less information than a well-crafted longer one because the short sentences don't show the links between key elements.

- Hot spots: Words at the beginning and at the end of a sentence have stronger emphasis than those in the middle.

- First write like you speak; then write like you write

- Yaffe's Law: If you give people what they want first, they are likely to accept anything else you want them to have. If you give them what you want first, chances are they won't accept anything at all.

- Text is visual. Used as Steve Jobs did, text draws 100 percent audience attention. With "text visuals," there are no extraneous details to dilute audience attention.

- Silence is golden-especially when you need to say something important.

- There is no such thing as a slide presentation. Slides only support the presentation; they should never be confused for the presentation itself.

- If you ever feel that what you are showing is becoming more important than what you are saying, delete the slides, tear up your speech, and start over again.

\begin{abstract}
About the Author
Philip Yaffe was born in Boston, Massachusetts, in 1942 and grew up in Los Angeles, where he graduated from the University of California with a degree in mathematics and physics. In his senior year, he was also editor-in-chief of the Daily Bruin, UCLA's daily student newspaper. He has more than 40 years of experience in journalism and international marketing communication. At various points in his career, he has been a teacher of journalism, a reporter/feature writer with The Wall Street Journal, an account executive with a major international press relations agency, European marketing communication director with two major international companies, and a founding partner of a specialized marketing communication agency in Brussels, Belgium, where he has lived since 1974 . He is the author of more than 30 books, which can be found easily in Amazon Kindle.
\end{abstract}

DOI: $10.1145 / 3361720$ 